Olga M.Ilchenko, PhD, prof.

\title{
WRITING FOR INTERNATIONAL AUDIENCES
}

The emergence of a global language can influence the structure of other languages. There are no precedents in human history for what happens to languages, in such circumstances of rapid change. There has never been a time when so many nations were needing to talk to each other so much. There has never been a time whew so many people wished to travel to so many places. There has never been such a strain placed on the conventional resources of translating and interpreting. Never has the need for more widespread bilingualism been greater, to ease the burden placed on the professional few. And never has there been a more urgent need for a global language.

(David Crystal)

What kind of English is to be used with global communication in mind? A possible answer to this challenge may be rooted in the realm of ethnic specificity. In other words, it is basically about cultural variation in discourse. It was J. Galtung who first described four basic "intellectual styles" (ways of presenting thoughts in writing), i.e. "Saxonic", "Gallic", "Teutonic", and "Nipponic" [5]. Some time earlier R. Kaplan noticed similar phenomenon - cross-cultural differences in cultural thought patterns - English, Semitic, Russian, Romance and Oriental ones [7]. Consider just one example: the writings by Ukrainians and Russians can employ a lot of digressions (with sentences beginning on one page and ending on another), which makes them barely readable for AngloAmerican audience.

On the other hand, Dwight Atkinson in his paper, "Writing and culture in the post-process era", argues that whereas the culture concept has traditionally been used to investigate differences and cultural "purity", the current notion of culture takes into account continuity, universality, and hybridity, as well as the full range of social and cultural contexts impacting second-language (L2) writing [2]. We feel that the same thing holds true for non-native speakers (NNS) of English as well. The aim of this paper is to outline some basic ideas for communicating with international audiences in English in light of linguistic and culture specific issues.

A quest for universality and overall comprehensibility of information has brought about the idea of "plain English", promoting crystal-clear language. Plain English is defined as writing that the intended audience can read, understand and act upon the first time they read it $[1 ; 4]$. Plain English takes into consideration design and layout as well as language. It 
emphasizes avoiding clichés and jargon and suggests that we use "every day" instead of "on a daily basis", "conclusion" in place of "bottom line" etc.

The readers need to find information quickly. They skim and scan the text before reading it. Thus it is necessary to facilitate information decoding. It is quite easy by employing several techniques. First, the text should be properly structured in a clearcut, linear manner. Sentences should be short and effective, making the text as consistent and lucid as possible. The old rule stating that the new information is usually followed by an old one, still holds true. Another useful point is about employing extensive clarifying, paraphrasing and exemplifying when expressing ideas. For instance:

As an example, in the last few years, the global engineering workforce has undergone substantial change, and the U.S workforce, in particular, shows trends that we would never have anticipated 15 or 20 years ago-the outsourcing of mainstream engineering jobs; increasing reliance on foreign-born Ph.D. graduates; and the need for retraining engineers to enable them to change careers a number of times before retirement.

The term disruptive technology was coined by Clayton $M$. Christensen and introduced in his 1995 article "Disruptive Technologies: Catching the Wave." The concept of disruptive technology continues a long tradition of the identification of radical technical change in the study of innovation by economists, and the development of tools for its management at a firm or policy level. (Perlman.)

Overall, using plain, simple language translates into:

- avoiding slang, jargon, idioms, humor, as well as symbols, acronyms, specific terminology. If one has to use some terms, brand names and/or abbreviations, clear definitions and thorough explainations are required upon introduction.

- using international words (though some of them may actually be false cognates or "false friends"). For example, in Russian and Ukrainian,"decade" means not "10 years", but "10 days"; the word that sounds similar to English "actual" means not "real" but "current, present-day", and "aggressive" conveys only negative connotation of "hostile, offensive".

- using simple rather than phrasal verbs.

- employing the words that are easier to pronounce.

For example, it is generally preferable to use "for example" instead of "e.g.", "jargon" rather than "gobbledygook", "excellent" in place of 
"superb", "24 hours a day 7 days a week" rather than 24/7, "to cancel/to postpone" instead of "to call off"; "to work really hard" vs. "to burn midnight oil", "bureaucracy" instead of "red tape". Also, when dealing with international audiences, expressing time becomes critical. Some countries the 24 hour clock, others use a.m. and p.m. Moreover, in Europe, the day ends at 24.00 and starts at 00 (which is technically speaking, the same). In the US, 12:00 a.m. is the beginning of the day. By the way, when making a hotel reservation, Russians and Ukrainians will speak of the mumber of "days", while in English we use the word "nights". It is a good idea to use International Standard (ISO) for expressing time, for example: 17:30:00 (which is 5.30 p.m.). One more confusing thing is date. The date 05/07/08, which could be put 05-07-08, 05.07.08, can mean "May 7, 2008" or "July 5, 2008". International standard (ISO) requires writing the name of the month and the year in full, e.g. 5 July 2008.

A very important thing is keeping a document succinct. Limiting oneself to discussing no more than three points at one time, with constant focusing on them, is a must. The sentences should be as short as possible (no more than approximately 27 words in one sentence). Appropriate examples, emphasizing key ideas by using baldface, bullets, as well as listings of items (that should be parallel in structure) are of great importance. For example:

Marketers direct the flow of goods and services from producers to consumers. Marketers attempt to bring both the producers and the consumers together.

- Producers are organizations that create goods and services.

- Consumers are those who buy and ore/use goods and services for personal satisfaction.

- Industrial buyers are those who buy goods and services for business, rather than or personal use. (Peterson).

Another tricky point is avoiding ambiguity:

"I once shot an elephant in my pajamas. How he got in my pajams I'll never know." (Groucho Marx).

Ask the members of the group to provide any punctuation necessary to the following seven-word sentence: "Woman without her man is a savage." The average male chauvinist will quickly respond that the sentence needs no punctuation, and he is correct. There will be a few pedants among the male chauvinists who will place balancing commas around the prepositional phrase: "Woman, without her man, is a savage". Grammatically, this is also correct. A feminist, however, and an occasional liberated man, will place a dash after "woman" and a comma after "her". Then we have "Woman - without her, man is a savage" (Day). 
Probably the best compilation of such cases comes from Jeff Gray's "Collection of Ambiguous or Inconsistent/Incomplete Statements". Consider the following:

Fine for Parking Here.

Bargain Basement Upstairs.

Illiterate? Write today for free help.

We do not tear your clothing with machinery. We do it carefully by hand.

Please wait for hostess to be seated.

- BUCHAREST HOTEL

The lift is being fixed for the next day. During that time we regret that you will be unbearable.

- BUDAPEST ZOO

Please do not feed the animals. If you have any suitable food, give it to the guard on duty.

- BANGKOK DRY CLEANER

Drop your trousers here for best results.

- ROME LAUNDRY

Ladies, leave your clothes here and spend the afternoon having a good time.

- PARIS HOTEL

Please leave your values at the front desk. [6]

On the other hand, ambiguous statements can be truly invaluable in some cases. Several gems of double meaning were created by Robert Thornton, a professor of economics at Lehigh University in Bethlehem, Pennsylvania. Thornton was frustrated about having to write letters of recommendation for people with dubious qualifications, so he put together an arsenal of statements that can be read two ways. He calls his collection the Lexicon of Inconspicuously Ambiguous Recommendations, or LIAR, for short. Some examples from LIAR:

About a lazy person: "In my opinion, you will be very fortunate to get this person to work for you."

To describe an ex-employee who had problems getting along with fellow workers: "I am pleased to say that this candidate is a former colleague of mine".

To describe a person with lackluster credentials: "All in all, I cannot say enough good things about this candidate or recommend him too highly." [9].

In 1988, the MITRE Corporation of Bedford, Massachusetts (E.R. Buley, L.J.Moore, and M.F Owess prepared a list of requirements to avoid ambiguities when preparing or reviewing a specification. The authors suggest to be careful with the following.

A CHECKLIST FOR FUZZY REQUIREMENTS 
- Incomplete lists ending with "etc.," "and/or," and "TBD."

- Vague words and phrases such as "generally," "normally," "to the

- greatest extent," and "where practicable."

- Implied certainty, flagged by words such as "always," "never," "all," or "every."

- Passive voice, such as "the counter is set." (By whom or what?)

- Every pronoun, particularly "it" or "its." Each should have an explicit and unmistakable reference.

- Comparatives, such as "earliest," "latest," "highest."

- Words and phrases that cannot be quantified, such as flexible, achievable, efficient, adequate, minimum required, minimum acceptable, better, higher, faster, less, slower, infrequent, to the extent practicable, where applicable. [3].

A caveat regarding relevant Active or Passive voice preference is needed here. A general adsvice is to use Active rather than Passive voice.

However, there are cases when they may well be used interchangeably, though the first version below is much less "humanized" than the other five:

It could be concluded...

One can conclude ...

I conclude

We conclude ...

The conclusion is...

You can conclude ...

Let us note here that while it is natural to use explicit "I" in English, many other languages - for example, Slavic - consider it impolite. Therefore, it would be a safer bet to stick with universal pluralis auctoris "we" - a case of coexistence of both. Another relevant point is about "personalizing" discourse through various linguistic devices conveying "you and I" attitude. Here belong phrases like let us/ let's; (now) let's turn to; you could/may; (please) note; consider; think of etc.

The Passive voice is used to create the so-called "objectivity effect"; concentrtate on the subject itself (especially in the language of science), usually by mentioning it in the very beginning of the sentence. Consider several typical examples:

The models were developed from scratch.

Much has been written about various aspects related to standards and standardization (IEEE Spectrum).

It is also preferable to use modal verbs (specifically, can, could, may, might) in passive constructions, especially when writing about examples and conclusions:

A simple example can be used to illustrate the approach described here. 
It could be concluded that this is less important.

The matter may be elucidated by further analysis (IEEE Spectrum).

Also, it was noticed that the so called "active" verbs (e.g. conduct, connect) are "neutralized" by voice. On the contrary, "passive" verbs (e.g. indicate, reveal) tend to be used in Active voice [8].

One more point about Passive voice preference: it is widely used when subject is ether unimportant (e.g. the agenda was changed yesterday) or undesirable (for some reasons) to mention (e.g. authorization is required; the project was rejected; the document isn't filled out correctly).

At this point there are more issues to consider. Another tricky point is culture specific evaluations. The words challenge/challenging (challenging - needing the full use of one's abilities and effort; difficult, but in an interesting way; difficult but not impossible) are frequently used in English instead of difficulty/difficult. However, it is sometimes advisable to explain the foreign audiences the true meaning of "challenge", emphasizing that it is basically about "difficulties" - it is about the problems that challenge someone or something. The evaluation "interesting" (which in English means "important but somewhat unexpected or strange"), in Slavic languages actually conveys not just "soso", but much higher praise. Some universal etiquette issues should also be taken into account. They are basically about cushioning negative statements, implying alternative approaches (yes...but...), and using "diplomatic" language", e.g.:

It may or may not be a problem.

It depends. It's not necessarily good. Nor is it bad.

Unfortunately, the situation looks potentially unwinnable.

When addressing foreign partners, it's a safe bet to use their last name. It should be noted that today - in writing letters - a warm greeting and especially a "small talk" line before proceeding to business is an important etiquette element:

Dear Mr. Green,

Thank you for renewing your membership for 2009. You know how important it is to stay up-to-date with cutting-edge technology breakthroughs.

Please take a moment to update or confirm the information in your technical interest profile. With this data, we can continue to send you timely information in your particular areas of interest.

Finally, it is a good idea to avoid cultural references such as politics (including some historical events and historical figures), religion and money. The same holds true for humor, idioms, word play. But that doesn't 
alter the fact that some internationally recognizable idioms should be used in a proper context, e.g. "salt of the earth", "to iron out (matters)" etc. For example:

The rapid pace of technology and its importance to our economy requires

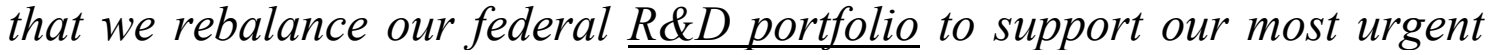
priorities...We find ourselves at a crossroads in history-operating within a new economy - and we'd better roll up our sleeves and get busy. (Perlman).

All of the above leads us to believe that adressing any audience, including international, is about avoiding miscommunication, and making the message clear, easily understandable and comprehensible by any person in any country of the world. Simply put, it about "localizing the international and internationalizing the local". The key is to finally persuade the readers - in friendly manner, but in the first place, to make the audience feel good, to "humanize" the communication itself.

\section{Jimepamypa}

1. Рубашова Л.М. Національна ідентичність англійської мови чи ii міжнародна «зрозумілість» : вибір на користь спрощення? / Леся Михайлівна Рубашова // Лінгвістика XXI століття : нові дослідження і перспективи / гол. ред. Алла Дмитрівна Бєлова. - К: Логос, 2007. - С. 218229.

2. Atkinson D. Writing and culture in the post-process era / Dwight Atkinson // Journal of Second Language Writing. - 2003. - Vol. 12, № 1. - P. 49-63.

3. Buley E.R, Moore L.J., Owess M.F. B5 (SRS/IRS) Specification Guidelines, Technical Report M88-57, ESD-TR-88-337. MITRE, Bedford, MA, USA / E.R. Buley, L.J. Moore, M.F. Owess, 1988.

4. Crystal D. English as a global language / David Crystal. - Cambridge: Cambridge University Press, 1998. - 228 p.

5. Galtung J. Struktur, Kultur und Intellektueller Stil in das Fremde und das Eigene / John Galtung. - Munich: Iudicium Verlag, 1985. - P. 151-193.

6. Gray J. Collection of Ambiguous or Inconsistent/Incomplete Statements / Jeff Gray. - TN: Vanderbilt University, Nashville, 2000. - Режим доступу:

http://www.gray-area.org/Research/Ambig/

7. Kaplan R.B. Cultural thought patterns in intercultural education / Robert B. Kaplan // Language Learning. - 1996. - Vol. 16, №1. - P. 1-20.

8. Lachowicz D. On the use of the passive voice for objectivity, author responsibility, and hedging in EST / Dobroslaw Lachowicz // Science of Science. - 1981. - Vol. 2, № 2. - P. 105-115.

9. Thornton R.J. L.I.A.R.: The Lexicon of Intentionally Ambiguous Recommendations / Robert J. Thornton. - Barnes \& Noble, 2005. -114 p.

Докерела ілюстративного матеріалу:

Day R.A. How to Write and Publish a Scientific Paper / R.A. Day. - Phoenix: Oryx Press, 1988.

Groucho Marx.com - http://www.groucho-marx.com/

IEEE Spectrum INT (2003-2009)

Perlman B. MTT-S E-Newsletter. - February, 2009. 
Peterson R.T. Principles of Marketing / R.T. Peterson. - Harcourt Brace Jovanovich. NYL, 1989.

The present paper deals with writing for international audiences from the perspective of "localizing international", "internationalizing the local" and overall "humanizing"communication. Issues regarding using plain language, expressing time, date, as well as (im)personalizing devices, linearity and sentence length, culture specific elements are considered. Special attention is given to avoiding fuzziness and ambiguity.

Key words: written language, international audiences, information decoding, plain English, ambiguity, humanizing communication

В статье рассматриваются е аспекты письменной коммукации на английском языке в свете национального и интернационального и гуманизации общения. Анализируются особености упрощения языка, обозначения времени, даты, выражения (де)персонализации, линеарного построения текста и длины предложений, релевантным вопросам лингвокультурного характера. Также уделяется внимание вопросам избегания синтаксической омонимии.

Ключевые слова: письменная коммуникация, международная аудитория, декодирование информации, упрощенный английский язык, синтаксическая омонимия, гуманизация общения 